\title{
PARAMETER TINDAK TUTUR SANTRI DAN USTAZAH PADA PEMBELAJARAN KITAB AMSILATI DI PESANTREN DARUSSALAM
}

\author{
Aulia Normalita \\ Universitas Sebelas Maret Surakarta \\ Pos-el: aulianormalita277@gmail.com
}

Diserahkan: 14 Juli 2020, Direvisi: 25 Oktober 2020, Diterima: 11 Februari 2021

\begin{abstract}
Verbal language forms of civility are found in the classroom. This research aims to describe the parameters of the follow-up and Ustazah in the study of Amsilati in Pesantren Darussalam using Grice theory. Data is derived from the speech and Ustazah in the moment of learning Amsilati. Data collection using qualitative Descripstif method with observation technique. Data collection through observation, vision, hearing and directly involved with speakers. The results of the study showed that (2) data in the form of violation of Maksim quantity, (1) Data adhering to quantity Maksim. (1) Quality data violations, and (1) data complying with the quality of Maksim. Then (1) The data complies with the relevance Maksim, and (1) The last data in the form of violation of execution. It shows more violations committed than adhering to Grice's principles of cooperation.
\end{abstract}

Keywords: speech-act, students and Ustazah, Book of Amsilati. 


\begin{abstract}
Abstrak
Bentuk kesantunan berbahasa secara verbal ditemukan di dalam kelas. Penelitian ini bertujuan mendeskripsikan parameter tindak tutur santri dan ustazah pada pembelajaran Amsilati di Pesantren Darussalam dengan menggunakan teori Grice. Data diambil dari tuturan santri dan ustazah pada saat pembelajaran Amsilati berlangsung.Teknik pengumpulan data menggunakan metode deskripstif kualitatif denganteknik observasi. Adapun pengumpulan data dilakukan melalui pengamatan, penglihatan, pendengaran dan terlibat secara langsung dengan penutur.Hasil penelitian menunjukkan bahwa terdapat 2 data berbentuk pelanggaran maksim kuantitas, 1 data mematuhi maksim kuantitas.1 data pelanggaran maksim kualitas, dan 1 datamematuhi maksim kualitas. Kemudian 1 data mematuhi maksim relevansi, dan 1 data terakhir berupa pelanggaran maksim pelaksanaan. Hal tersebut menunjukkan lebih banyak pelanggaran yang dilakukan dari pada mematuhi prinsip kerja sama Grice.
\end{abstract}

Kata Kunci: tindak tutur, santri dan ustazah, Kitab Amsilati.

\title{
PENDAHULUAN
}

Salah satu tindak tutur yang mudah diamati adalah tindak tutur pada saat pembelajaran di dalam kelas. Tindak tutur atau speech act adalah bentuk aktivitas mengujarkan atau menuturkan. Rustono(dalam Febriasari, 2018: 142) menjelaskan bahwa dalam pragmatik tindak tutur sebagai entitas yang bersifat sentral. Peristiwa tutur dalam hal ini melibatkan keaktifan guru dalam menyampaikan materi secara jelas, singkat, dan mudah dipahami. Seperti yang diungkapkan oleh Sonhaji (2014: 31) guru mengajak siswa untuk berkomunikasi secara aktif, sedangkan siswa diharapkan dapat merespon dengan baik tuturan yang disampaikan oleh guru. Dari (2017: 11) mengungkapkan bahwa di dalam masyarakat sendiri kesantunan bersifat relatif. Artinya ujaran tertentu dapat dikatakan santun dan tidak santun di dalam kelompok masyarakat tertentu. 
Sependapat dengan Fakhrurrazi (2018: 88) yang menyatakan mengenai keberhasilan dalam proses pembelajaran di kelas sematamata tidak hanya bergantung pada guru, tetapi juga melibatkan keaktifan siswa. Kesantunan berbahasa juga digunakan sebagai medium untuk saling menghormati penutur dan lawan tutur. Hal tersebut senada dengan pendapat Markhamah (Fitria Cahyaningrum, 2018) bahwa pada dasarnya kesantunan berbahasa merupakan teknik penutur dalam berkomunikasi untuk menjaga mitra tutur agar tidak merasa tersinggung. Kesantunan berbahasa juga dipengaruhi adanya faktor sosial budaya dalam masyarakat. Hal tersebut berkaitan erat dengan prinsip kesopanan yang mempengaruhi tingkah laku sosial dalam suatu masyarakat (Sulistyo dalam Cahyaningrum, 2018: 72).

Kemudian, Siahan (dalam Budiwati, 2017: 2) menambahkan bahwa dalam masyarakat penutur yang tidak memahami kode etik seperti apa yang dibicarakan akan menjadi perhatian dari berbagai situasi. Ia menambahkan bahwa penutur yang sembrono dapat dianggap melanggar norma sosial. Wijayanti (2018) mendefinisikan tindak tutur menjadi sesuatu yang penting dan berperan aktif dalam menganalisis topik pragmatik yang diantaranya berperan sebagai prinsip kerja sama dan prinsip kesantunan.Kesantunan sendiri adalah adat atau kebiasaan yang menyangkut perilaku dalam berlaku di masyarakat.

Dalam situasi kehidupan sehari-hari, sikap yang santun akan memberi dampak positif terhadap hubungan sosial masyarakat (Maulidi , 2015). Itulah sebabnya perlu diperhatikan ketika hendak bertutur dan berlaku di masyarakat,apabila salah bertutur akan memberikan dampak negatif terhadap diri sendiri dan pandangan dari masyarakat. Selanjutnya, Brown dan Levinson (dalam Nurjamily, 2015) meneyebutkan tiga skala yang dapat dipakai untuk mengukur kesantunan dalam bermasyarakat. (a) jarak sosial (b) hubungan kekuasaan (c) tingkat kedudukan relatif pada situasi tertentu dan situasi lain.

Menurut Leech (dalam Gunawan, 2013: 9) mengungkapkan bahwasejatinya manusia pada umunya lebih senang dan 
menghendaki untuk mengungkapkan pendapat yang sopan daripada pendapat yang tidak sopan. Sebab cecara umum kesantunan berbahasa adalah perihalmenjaga harga diri. Sementara Brown dan Levinson (dalam Gunawan, 2013: 9) memopulerkan dengan istilah Tindakan Mengancam Muka (FTA) menjaga keterancaman muka atau menjaga harga diri penting dilakukan penutur dan mitra tutur. Hal ini bertujuan untuk menghindari saling ketersinggungan yang melibatkan tutur kata berujung konflik.

\section{KAJIAN LITERATUR}

\section{Prinsip Kerja Sama Grice}

Penelitian ini menggunakan teori prinsip kerja sama Grice. Adapun prinsip-prinsip tersebut secara lengkap dikemukakan dalam prinsip kerja sama Grice (1975) yang mencakup empat maksim. Pertama, maksim kuantitas (Maxim of Quantity) yaitu informasi yang diberikan tidak boleh melebihi informasi yang di butuhkan olehmitra tutur. Kedua, maksmim kualitas (Maxim of Quality) yaitupenyampaian informasi oleh penutur diharapkan sesuai fakta dan nyata adanya dalam bertutur.Fakta harus di dukung dan didasarkan pada bukti yang jelas.Ketiga maksim Relevansi (Maxim Relevance) agar terjalin hubungan yang baik, yakni dengan memberikan kontribusi yang relevan pada masing-masing tuturan yang sedang dibicarakan.Bicaralah yang relevan atau yang berguna (Kuntarto, 2016: 35).

Keempat maksim pelaksanaan (Maxim of manner). Pada maksim pelaksanaan ini, penutur maupun mitra tutur diharuskan bertutur secara langsung, tidak kabur dan jelas. Berdasar pada maksim pelaksanaan tersebut, apabila penutur atau mitra tutur tidak mempertimbangkan ketentuan yang berlaku, maka hal tersebut dapat dikatakan sebagai pelanggar prinsip kerja sama Grice. Pada saat berkomunikasi peserta tutur perlu mempertimbangkan prinsipprinsip sebagai berikut; (1) kejelasan, (2) kepadatan, (3) dan prinsip kelangsungan yang telah dituangkan di dalam prinsip kerja sama Grice. (Rahardi, 2005:52). 


\section{Santri Dan Kitab Amsilaty}

KitabAmsilaty merupakan salah satu mata pelajaran di Pesantren Darussalam. Selama pembelajaran kitab ini berlangsung, di dalamnya banyak penjelasan bahasa Indonesia maupun Arab sehingga memungkinkan para santri dan ustazah menggunakan metode komunikatif dan sesi tanya jawab lebih banyak. Pada umumnya penggunaan santri merujuk pada orang-orang yang sedang mengaji atau nyantri di pondok pesantren. Salah satu pendidikan Islam di Indonesia adalah pesantren. Pesantren merupakan struktur internal yang memiliki kekhasan tersendiri dalam membedakannya dari lembaga-lembaga pendidikan Islam lainnya. Hal tersebut yang menjadikan pesantren dengan ruh tradisionalnya tetap eksis dan bertahan hingga sekarang (Zuhdiyah, 2013: 193).

Dunia pesantren tidak akan pernah luput dari yang namanya kiai, santri, dan tradisi. Santri inilah yang mulai membentuk tradisitradisi pesantren termasuk menciptakan berbagai macam bahasa di dalamnya. Menurut Fuad (dalam Muhakamurrohmah: 2014) kata pesantren bermula dari kata santri yang berawalan "pe" dan akhiran "an" kemudian pengucapan kata tersebut diubah menjadi "en" (pesantren). Kurniasih (dalam Mansur 2017) mengatakan bahwa unsur dalam pesantren setidaknya memiliki lima komponen dasar, yakni ada santri, masjid, pondok, kiai, dan kitab-kitab klasik sebagai media pembelajaran.Kelima unsur pesantren tersebut menjadi komponen utama terbentuknya komunikasi bahasa secara langsung. Penggunaan bahasa sangat nampak ketika santri berinteraksi dengan kiai, pengurus, ustaz maupun ustazah(Kurniasih dalam Hisyam, 2017).

Pondok pesantren pula sebagai tempat menimba ilmu para santri yang mengfokuskan pada keilmuan agama (Normalita dan Oktavia, 2019: 25). Di pesantren, kitab kuning dijadikan sebagai gerbang bagi para pelajar Muslim untuk menggali ilmu-ilmu agama Islam. Literatur semacam ini telah dipelajari di Indonesia sebelum era kolonial yang pada saat itu hanya dipelajari di madrasah, tetapi juga dikaji, dilestarikan dan diterapkan di pesantren (Huda dalam 
Rasyidin, 2017: 42). Seiring berkembangnya zaman, peningkatan karya-karya dari berbagai macam kitab mulai beredar, adapun faktor-faktor perkembangannya dijelaskan oleh Departemen Agama RI (dalam Hanani, 2017: 3) bahwa jumlah kitab kuning yang beredar di Indonesia sangat signifikan dan mengalami peningkatan. Adapun faktor penyebab peningkatan tersebut disinyalir oleh: (1) banyaknya kiai yang menulis kitab sendiri, baik menggunakan bahasa Arab, Melayu (Pegon) maupun menggunakan bahasa lokal. (2) penyederhanaan (mukhtashar) dilakukan oleh beberapa kiai terhadap kitab-kitab yang ada dalam rangka penyesuaian materi, bahasa, maupun pembahasannya.

Salah satu mukhtasar produk kiai Indonesia yang menulis kitab sendiri adalah H. Taufiqul Hakim berwujud Kitab Amsilati yang ditulis menggunakan bahasa Arab dan Bahasa Indonesia. Amsilati adalah kitab yang berisi metode praktis mendalami Al quran dan membaca kitab kuning secara cepat bagi para pemula. Kitab ini telah banyak diajarkan di pesantren-pesantren Indonesia. Melalui pembelajaran metode tersebut terutama nahwu dan sharaf diharapkan dapat memberikan bekal kepada santri untuk dapat membaca kitab kuning (Fikri, 2018: 128). Metode amtsilati adalah metode terbaru yang merupakan cara cepat untuk mempelajari kitab kuning (Hidayah, 2018: 225). Perwujudan Kitab Amsilati merupakanhasil (ringkasan dan intisari kitab Alfiyah Ibnu Malik) yang terdiri dari 1002 bait nazham (Malik, 1408).

Hakim (2003) membagi hasil meringkasan nadzam-nadzam tersebut menjadilima jilid; jilid pertama tentang dasar hukum nahwu shorof.Jilid kedua tantang At-tamrin yang berisi tentang latihan-latihan soal dalam membaca kitab kuning. Jilid ketiga tentang Muhimmah atau tatimmah yakni berisi mengenai penerapan dari rumus-rumus yang ada di qoidah. Jilid empat berisi tentang pendalaman kosakata, pola-pola kata, tambahan-tambahan dalam kata, bentuk masa lalu, masa sekarang, perintah dan lain-lain yang berada di dalam kamus at taufiq. Jilid lima mencari kedudukan dari kitab yang dibaca atau dipelajari serta menerapkan rumus-rumus dari semua jilid yang telah dipelajari sebelumnya. Berdasarkan 
kelima jilid yang telah dipaparkan, Hakim (2003) juga menuliskan khulasoh (ringkasan) nadzoman, mulai dari jilid satu sampai jilid lima. Pembelajaran kitab-kitab klasik memang salah satu khasnya pesantren, diantara sekian banyak kitab yang digunakan sebagai pembelajaran di pesantren. Amsilati dipilih sebagai salah satu kitab yang digunakan untuk bahan ajar di pesantren Darussalam.

Penelitian relevandilakukan oleh Gunawan (2013) dengan judul Wujud Kesantunan Berbahasa Mahasiswa Terhadap Dosen Di STAIN Kendari. Penelitian tersenut memfokuskan pada wujud percakapan antara dosen dan mahasiswa yang direalisasikan berupa modus kalimat dengan hasil penelusuran data meliputi bentuk sintaksisnya, kalimat berdasarpada kelengkapan unsurnya, dan berdasar pada pola urutannya. Perbedaan penelitian ini dengan penelitian yang dilakukan oleh oleh Gunawan tersebutterdapat pada objek dan kajian yang digunakan.Gunanawan menggunakan kajian Sosiopragmatik dan objek kajian yang diteliti berasal dari tuturan mahasiswa dan dosen.Sedangkan penelitian ini menggunakan kajian Pragmatikdengan objek santri dan ustzah.Persamaan terdapat pada ranah yang diambil, yakni mengenai kesantunan berbahasa.

Penelitian ini dilakukan di pesantren Darussalamyang berada di sekitar kampus IAIN Surakarta. Penelitian yang akan dilakukan berfokus pada tindak tutur antara santri dan ustzah pada pembelajaran kitab Amsilaty. Peran ustazah di lingkungan Pondok pesantren cukup besar, melalui dukungan sosial dari ustazah berupa perhatian, semangat, dan kasih sayang akan membuat santri merasa dicintai dan diperhatikan (Dewi, 2019: 3). Berdasarkan hal tersebut, tingkat keakraban santri akan muncul terhadap ustazah. Penelitian ini akan melihat sejauh mana kesopanan tindak tutur yang dilakukan santri ketika berinteraksi dengan ustazah pada saat pembelajaran di dalam kelas.

Pada konteks ini selisih umur antara santri dan ustazahnya hanya berkisar dua sampai tiga tahun, sehingga tingkat keakraban yang terjalin antara keduanya begitu dekat. Sejalan dengan Rahmawati (2017: 4) bahwa mengajar kuliah dan membantu 
mengajar di pondok merupakan bentuk pengabdian. Oleh sebab itu, peneliti ingin mengetahui batas-batas kesopanan yang dilakukan para santri. Apakah tetap menghormati dalam situasi dan kondisi tertentu ataukah sikap yang ditunjukkan santri terhadap ustazah sama saja, tidak terbatas ruang dan waktu. Sebab dari beberapa materi utama, yang harus ditanamkan kepada seorang murid adalah bagaimana perilaku menghormati orang tua, ustaz dan ustazah, guru, dan orang lain. (Anita dkk, 2017: 299).Berdasarkan latar belakang di atas, penelitian ini akan menganalisis prinsip kerja sama dengan objek santri dan ustazah yang berada di pondok pesantren Darussalam. Adapun pengambilan data akan dilakukan ketika pembelajaran Kitab Amsilati berlangsung.

\section{METODE PENELITIAN}

Penelitian ini menggunakan metode deskriptif kualitatif. Metode deskriptif dipilih karena metode ini dapat memberikan gambaran secara cermat mengenai individu, dan keadaan tuturanyang diteliti(Elvita Yenni, 2018). Data dalam penelitian ini adalah tindak tutur kesantunan dan pelanggaran berbahasa antara santri dan ustazah dalam pembelajaran kitab Amsilaty di kelas Wustho.Teknik pengumpulan data berupa observasi partisipatif. Menurut Sugiyono (2016: 227) observasi partisipatif akan memberikan data yang lebih tajam dan lengkap. Adapun akitivitas yang dilakukan dalam pengumpulan data adalah merekam, mengamati, melihat, mendengar, dan terlibat secara langsung di dalam kelas dengansantri dan ustazah. Alat perekam yang digunakan berupa gawaitanpa sepengetahuan objek, sehingga tidak akan mengganggu proses pembelajaran.

Teknik analisis data menggunakan model interaktif. Miles Huberman (dalam Sutopo, 2002: 91) membagi model interaktif menjadi tiga bagian yakni reduksi data, sajian data, dan penarikan kesimpulan. Data yang terkumpul selanjutkan akan direduksi atau dikurangi, kemudian disajikan sesuai dengan teori yang digunakan yakni kesantunan berbahasa Grice. Langkah terakhiryaitu penarikan 
kesimpulan dari data-data yang telah dianggap valid dengan teori. Adapun Jadwal Amsilati satu minggu sekali pada senin malam. Penelitian dilakukan pada bulan April 2018 minggu pertama dan kedua. Peneliti terlibat secara langsung, sebab peneliti merupakan santri di pesantren tersebut.

\section{HASIL DAN PEMBAHASAN}

\section{Data (1) Pelanggaran Maksim Kuantitas}

Ustazah : "Apakah yang dimaksud dengan fa'il? Alda jelaskan"

Santri : "Apa ya, sek Ustazah, sedang mencoba mengingat

Emh oh ya, fa'il atau pelaku hukumnya adalah rafa', dan pasti berupa isim atau kata yangdidahului huruf an atau anna".

Ustazah :"Apakah yang dimaksud dengan khobar?"

Santri : "Khobar adalah bagian kalimat yang

menyempurnakan faedah sehingga kalimat tersebut bisa dipahami,dimengerti dan mudah untuk diterapkan”

Data (1) berdasarkan percakapan antara Ustazah dan santri terlihat bahwa jawaban-jawaban yang diberikan kepada ustazah melampaui kebutuhan.Artinya, prinsip kerja Grice mengenai maksim kuantitas telah dilanggar.Pada kalimat di atas, ustazah atau penutur hanya bertanya seperlunya dengan kalimatApakah yang diamksud dengan fa'il?Kemudian dijawab berlebihan olehmitra tutur atau santri, dengan menambahkan kalimat basa-basi seperti Apa ya, sek Ustazah, sedang mencoba mengingat. Emh oh ya.

Kemudian pertanyaan kembali dilontarkan ustazah: Apakah yang dimaksud dengan khobar?Namun kembali ditimpali santri dengan jawaban yang berlebihan.Apabila dilihat berdasarkan dari Kitab Amsilati jilid tiga, jawaban yang tepat adalah Khobar adalah 
bagian kalimat yang menyempurnakan faedah sehingga kalimat tersebut bisa dipahami.Namun santri memberikan jawaban yang berlebihan dengan menambahkan kalimat dimengerti dan mudah untuk diterapkan.Dalam hal ini data (1) dapat dikatakan melanggar maksim kuantitas.

\section{Data (2) Pelanggaran Maksim Kuantitas}

Ustazah : "Coba Rizki, sebutkan macam-macam mubtada" Santri : "Eh opo wae to? Emm mubtada' yang berupa nama, mubtada yang berupa isim yang ada Al'nya, mubtada' yang berupa dhomir,mubtada' yang berupa isim isyaroh, seng apa Aul? Aduh lupa ustazah"

Santri : "iku lo, opo sih, mubtada' yang berupa isim maushul, mubtada' yang berupa idhofah,."

Santri : "Nah itu ustazah hahaha.."

Data (2) dalam konteks ini santri kembali melanggar maskim kuantitas. Ustazah hanya bertanya sebutkan macammacam mubtada' macam-macam mubtada', namun mitra tutur memberikan informasi yang melebihi jawaban yang diperlukan seperi pada jawaban santri "Eh opo wae toEmm mubtada" seng apa Aul? Aduh lupa ustazah". Hal ini telah melanggar prinsip kerja Grice sebab informasi yang diberikan lawan tutur melebihi kebutuhan.

Jawaban-jawaban yang tidak seharusnya justru diucapkan oleh santri dalam menanggapi pertanyaan ustazah kemudian ditambah dengan tuturan dari santri lain sehingga jawaban yang tidak diperlukan seperti gurauan, ketidakseriusan menimbulkan pelanggaran pada maksim kuantitas.

\section{Data (3) PematuhanMaksim Kuantitas}

Ustazah : (di kelas)"rafa' alamatnya apa?"

Santri : "Dhomah"

Ustazah : "Nasab alamatnya?"

Santri : "Fathah"

Ustazah :" Jer alamatnya?"

Santri : "Kasroh" (jawaban santri serempak) 
Ustazah : "Semua huruf termasuk huruf jer, hukumnya apa Leni?"

Santri : "Mabni"

Dari data (3) tampak bahwa percakapan yang terjadi antara santri dan Ustazah mematuhi maksim kuantitas.Percakapan yang dilakukan oleh Ustazah dengan mengajukan pertanyaan kepada semua santri dan dijawab serempak oleh santri, seperti; dhomah, fathah, dan kasroh.Kemudian pertanyaan kembali diajukan oleh Ustazah kepada personal santri Nasab alamatnya apa Leni?” dan santri menjawab dengan jawaban yang informatif serta sesuai dengan yang dikehendaki maksim kuantitas yakni apa yang dikomunikasikan oleh mitra tutur cukup seperlunya atau sesuai dengan yang diperlukan saja. Jawaban yang diberikan begitu informatif sebab di dalam kaidah Jurumiyah dengan menggunakan metode Amsilati, alamat dari Rafa' ada empat yaitu dhomah, wawu, alif, dan nun.Namun, yang sering digunakan sebagai tanda pokok dari alamat Rafa' ialah dhomah. Jawaban dari santri sudah benar sebab ustazah hanya menanyakan secara pokok alamat dari Rafa' nasab, dan jer.

\section{Data (4) Pelanggaran Maksim Kualitas}

Ustazah : “Apa yang dinamakan isim nakiroh?jelasakan coba Sinta"

Santri : "Isim nakiroh ialah isim yang menunjukkan makna umum dan bisa menerima adanya al"

Ustazah : "Dasarnya mana? Halaman berapa?".

Santri : :......”(diam tidak bisa menjawab)

Data (4) hasil percakapan antara santri dan ustazah melanggar maksim kualitas.Pada saat Ustazah menanyakan Dasarnya mana? Halaman berapa? Atau buktinya mana, santri atau lawan tutur hanya diam dan tidak dapat memberikan bukti dari pengertian yang telah dijawabnya. Beberapa faktor umum yang membuat santri tidak dapat menjawab pertanyaan dari ustazah selama pelajaran Amsilati diantaranya adalah lupa, tidak belajar, dan bingung. Hal ini 
yang kerap kali menjadikan pertanyaan-pertanyaan yang diberikan ustazah tidak terjawab dan bertele-tele. Pada data (4) di atas dapat dikatakan sebagai pelanggaranmaksim kualitaskarena mitra tutur tidak dapat memberikan bukti dan fakta atas apa yang dituturkannya sehingga hanya memberikan respon kepada Ustazah.

\section{Data (5) Pematuhan Maksim Kualitas}

Ustazah : "sebutkan rumus utama beserta dasarnya, Aulia jelaskan"

Santri : "yang dimaksud rumus utama adalah, bedakan setiap kata antara isim, fi'il, huruf"

Ustazah : "dasarnya mana Aulia?"

Santri : “isman' wa filan tsumma harfan mayyiza, lafdzom bima minal alamatikh riza, bedakno disik isim f'il lan huruf kanti tandane isim fi'il lan huruf"

Ustazah : "bagus,.."

Data (4) sangat berbeda dengan data (5) yang telah berhasil memenuhi maksim kualitas. Hal ini dibuktikan melalui jawaban santri yang berhasil memberikan dasar, fakta dan bukti kepada ustazah dari pertanyaan yang sebelumnya telah di jawab. Ketika ustazah menanyakan dasarnya mana? Santri seketika menjawab dengan memberikan jawaban yang sesuai, berupa dasar yang sesuai di buku amsilati jilid dua halaman 12. Pematuhan maksim kualitas pada data nomor 5 sebab mitra tutur mampu memberikan bukti yang sesuai fakta dari pertanyaan yang diberikan oleh penutur. Dengan demikian data tersebut masuk dalam pematuhan maksim kualitas.

\section{Data (6) PematuhanMaksim Relevan}

Ustazah : "Ida, minta tolong mejanya ditaruh sana ya?" Santri : "enggehustazah"

Ustazah : "sini kitabmu tak bawain"

Santri : "SuwunUstazah" (memberikan buku)

Data (6) tuturan di atas yang dilakukan oleh ustazah dan santri telah memenuhi maksim relevan. Sebab dalam percakpan di atas penutur dan mitra tutur keduanya sama-sama memberikan 
kontribusi, keuntungan satu sama lain. Pada konteks tersebut Ustazah meminta tolong kepada santri untuk meletakkan meja agar dikembalikan ke tempat semula. Kemudian ustazah pula yang menawarkan diri untuk membawakan kitabyang dibawa oleh santri tersebut. Hal ini memberikan keuntungan bagi keduanya.Ustazah tidak perlu mengembalikan meja ke tempat semula dan santri tidak kerepotan membawa kitabnya pada saat mengembalikan mejatersebut. Pematuhan maksim relevan terjadi dalam data ini sebab adanya kontribusi yang seimbang danmenguntungkan sehingga keduanya tidak ada yang dirugikan.

\section{Data (7) Pelanggaran Maksim Pelaksanaan}

Ustazah : "Ayo Ayu dibaca"

Santri : "Yang halaman berapa ustazah"

Ustazah : "Itu selanjutnya".

Cuplikan pada data (7) di atas memiliki kadar kejelasan yang rendah. Hal ini berdampak pada kadar kekaburan yang tinggi. Tuturan ustazah, Ayo Ayu dibacasama sekali tidak memberikan kejelasan tentang apa yang sebenarnya diminta oleh penutur. Kata baca dalam kalimat di atas mengandung kadar ketaksaan dan kekaburan yang sangat tinggi. Oleh sebab itu, kata itu dapat ditafsirkan bermacam-macam.Respon dari mitra tutur atau santri "Yang halaman berapa ustazah" juga memiliki ketaksaan yang sangat tinggi. Tuturan pada kata halaman berapa memiliki persepsi yang bermacam-macam. Tuturan dari data (7) di atas dapat dikatakan melanggar maksim pelaksanaan dalam prinsip kerja sama Grice.

Berdasarkan hasil dan pembahasan di atas, data-data yang ditemukan merupakan data murni apa adanya. Adapun mayoritas data yang muncul adalah bentuk-bentuk pelanggaran dari maksim kuantitas. Adanya pelangaraan disebabkan tingkat keakraban antara santri dan ustazah. Kelas yang diteliti merupakan kelas Wustho atau kelas tengah, para santri mayoritas semester lima, sedangkan ustazahnya semester tujuh. Adanya jarak umur maupun jarak semester yang tidak terpaut jauhmenjadikan Ustazah sebagai kakak dari para santri. Hal tersebutlah yang menambah keakraban dari 
keduanya. Sehingga banyak informasi yang tidak perlu diungkapkan pada saat ustazah mengajukan beberapa pertanyaan kepada santri saat pembelajaran amsilati. Ungkapan basa-basi yang tidak perlu ditunjukkan mengakibatkan konteks tuturan menjadi berlebihan, sehingga efeknya terjadi ketidakstabilan antara pertanyaan penutur dan jawaban mitra tutur.

Pesantren Darussalam merupakan pondok salafi, apabila dilihat dari segi pola komunikasi yang terjadi antara santri dan ustazah terlihat keakraban yang begitu baik. Pemahaman karakter satu dengan yang lain begitu mendalam. Oleh sebab itu, tingkat keakraban yang timbul dari keduanya begitu dekat dan hangat. Berbeda dengan pesantren modern, hubungan keduanya tidak lebih dari sekadar santri dan guru. Komunikasi yang muncul cenderung lebih kaku sebab minimnya kebiasaan untuk saling sapa antara kiai dan santri.

\section{PENUTUP}

Hasil penelitian menunjukkan bahwa fenomena kesantunan berbahasa antara santri dan ustazah pada saat pembelajaran kitab Amsilaty di Pondok Pesantren Darussalam tidak menentu. Fenomena tindak tutur yang ada di Pondok Pesantren Mahasiswa Darussalam pada saat pembelajara Kitab Amsilati di kelas antara santri dan ustazah menunjukkan lebih banyak pelanggaran yang dilakukan dari pada mematuhi prinsip kerja sama Grice. Terbukti bahwa data (1) dan (2) berbentuk pelanggaran maksim kuantitas. Data (3) mematuhi maksim kuantitas, data (4) pelanggaran maksim kualitas. Data (5) mematuhi maksim kualitas, data (6) mematuhi maksim relevansi, dan terakhir data (7) yang berupa pelanggaran maksim pelaksanaan.Berdasarkan data-data tersebut peneliti menemukan lebih banyak pelanggaran maksim kuantitas dari maksim-maksim lainnya. 


\section{DAFTAR PUSTAKA}

Anita, Nur dkk. Komunikasi Interpersonal Ustad dan Ustazah dalam Proses Membimbing Santri Upaya Memberikan Pemahaman Agama Pada Anak di TPA Al- Mukhayyarah. Jurnal Al-Bayan Vol. 23 No. 2 Juli - Desember 2017 (hal: 299).

Budiwarti Tri Rina. Kesantunan Berbahasa Mahasiswa dalam Berinteraksi dengan Dosen Universitas Ahmad Dahlan: Analisis Pragmatik. [Jurnal]. - Yogyakarta: The 5th Urecol Proceding, 2017.

Cahyaningrum, Fitria. dkk. Realisasi Kesantunan Berbahasa dalam Interaksi Kelas Di Sekolah Menengah Atas Berlatar Bahasa Jawa. JURNAL GRAMATIKA ISSN: 2442-8485 E-ISSN: 2460-6316(hal: 72).

Cahyaningrum, Fitria dkk. Kesantunan Berbahasa Siswa dalam Konteks Negosiasi di Sekolah Menengah Atas.[Jurnal]. [s.l.] : Jurnal Pena Indonesia, 2018. - 1 : Vol. 4.

Dari, Ayu Wulan dkk. Analisis Kesantunan Berbahasa Pada Kegiatan Pembelajaran Kelas VIII E SMPN 2 Kota Bengkulu Tahun Ajaran 2016/2017. Jurnal Korpus, Volume I, Nomor I, Agustus 2017(Hal: 11).

Dewi, Luthfi Puspita. 2019. Peran Dukungan Sosial Ustazah dan Kematangan Emosi Terhadap Penyesuaian Akademik Santriwati. Skripsi. Universitas Muhammadiyah Surakarta Prodi Psikologi. Fakultas Psikologi.

Elvita Yenni Yusriati, Ambar Wulan Sari. Pola Pengajaran Kesantunan Berbahasa Anak di Lingkungan Keluarga. [Jurnal]. - [s.l.] : Jurnal Tarbiyah, 2018. - 1 : Vol. 25.

Fakhrurrazi. Hakikat Pembelajaran yang Efektif. Jurnal At-Tafkir Vol. XI No. 1 Juni 2018 (hal: 88).

Febriasari, Diani dan Wenny Wijayanti.Kesantunan Berbahasa dalam Proses Pembelajaran di Sekolah Dasar. Jurnal Kredo Vol. 2 No. 1 Oktober 2018 (Hal: 142) 
Fikri, Wahyu Najib. Implementasi Metode Amsilati dalam Membaca Kitab Kuning Di Pondok Pesantren Hidayatul Mubtadiin Demak. POTENSIA: Jurnal Kependidikan Islam, Vol. 4, No. 2, Juli - Desember 2018 (Hal: 128).

Gunawan Fahmi Wujud Kesantunan Berbahasa Mahasiswa Terhadap Dosen di STAIN Kendari Kajian Pragmatik [Jurnal].Kendari : Journal Arbitrer, 2013. - Vol. 1.

Hakim, Taufiqul. 2003. Program Pemula Membaca KItab Kuning (Metode Praktis Mendalami Al Quran dan Membaca Kitab Kuning) Jilid 1. Jepara: Al Falah Offset.

Hakim, Taufiqul. 2003. Program Pemula Membaca KItab Kuning (Metode Praktis Mendalami Al Quran dan Membaca Kitab Kuning) Jilid 2. Jepara: Al Falah Offset.

Hakim, Taufiqul. 2003. Program Pemula Membaca KItab Kuning (Metode Praktis Mendalami Al Quran dan Membaca Kitab Kuning) Jilid 3. Jepara: Al Falah Offset.

Hakim, Taufiqul. 2003. Program Pemula Membaca KItab Kuning (Metode Praktis Mendalami Al Quran dan Membaca Kitab Kuning) Jilid 4. Jepara: Al Falah Offset.

Hakim, Taufiqul. 2003. Program Pemula Membaca KItab Kuning (Metode Praktis Mendalami Al Quran dan Membaca Kitab Kuning) Jilid 5. Jepara: Al Falah Offset.

Hakim, Taufiqul. 2003. Program Pemula Membaca KItab Kuning (Khulasoh). Jepara: Al Falah Offset.

Hanani, Nurul. Manajemen Pengembangan Pembelajaran Kitab Kuning. Realita Volume 15, No. 2 Tahun 2017 (hal: 3).

Hidayah, Basyhirotul. Penerapan Metode Amsilati dalam Penguasaan Kitab Kuning Di Pesantren Putri Al-AmanahTambakberas Jombang. Muróbbî: Jurnal Ilmu Pendidikan Volume 2, Nomor 2, September 2018 (Hal: 225).

Kuntarto, Eko dan Abdoel Ghafar. Manifestasi Prinsip kesantunan, Prinsip Kerja sama, dan Implikatur Percakapan pada Interaksi 
di Lingkungan Sekolah. Jurnal Ilmiah Universitas Batanghari Jambi Vol.16 No.3 Tahun 2016(Hal : 35).

Malik, Bin Abdullah. 1408. Nadzaman Khulasoh Alfiyah Ibnu Malik. Semarang: Pustaka Alawiyah.

Maulidi, Ahmad Kesantunan Berbahasa pada Media Jejaring Sosial Facebook. [Jurnal]. - [s.l.] : e-Jurnal Bahasantodea, 2015. Nomor 4 : Vol. Volume 3.

Muhamkamurrohmah Ahmad Pesantren: Santri, Kiai, dan Tradisi [Jurnal]. - [s.l.] : Jurnal Ibda', 2015. - Vol. 12.

Normalita, Aulia dan Wahyu Oktavia. Komunikasi Multilingual pada Komunitas Santri Pondok Pesantren Mahasiswa Darussalam

Di Kartasura. Jurnal IMAJERI Vol. 02, No. 1, pp. 24-31; September 2019(hal: 25).

Nurjamily Wa Orde Kesantunan Berbahasa Indonesia dalam Lingkungan Keluarga (Kajian Sosiopragmatik) [Jurnal]. [s.l.] : Jurnal Humanika, 2015. - Vol. 3.

Rahardi Kunjana. 2005. Pragmatik Kesantunan Imperatif Bahasa Indonesia. Yogyakarta : Erlangga.

Rahmawati, Ana Trisya. Pola Komunikasi Santri terhadap Kiai: Studi atas Alumni Pondok Modern dan Alumni Pondok Salaf. Academica - Vol. 1 No. 1, Januari - Juni 2017(hal: 4).

Rasyidin, Al. Pembelajaran Kitab Kuning di Pesantren Musthafawiyah, Mandailing Natal. JOURNAL OF CONTEMPORARY ISLAM AND MUSLIM SOCIETIES. VOL.1 NO.1 JANUARIJUNI2017 (hal: 42).

Sugiyono. 2016. Metode Penelitian Kuantitatif, Kualitatif, dan R\&D. Bangdung: Alfabeta.

Sutopo, H.B. 2002.Metodologi Penelitian Kualitatif. Surakarta: Sebelas Maret University Press.

Sonhaji. Konsep Manajemen Kelas dan Implikasinya dalam Pembelajaran. Jurnal Kependidikan, Vol. II No. 2 November 2014 (hal: 31). 
Zuhdiyah. Pendekatan Terpadu dalam Membentuk Karakter Santri di Pondok Pesantren Sabilul Hasanah Banyuasin III. Intizar, Vol. 19, No. 1, 2013(hal: 193).

Zuhriyah Dwi Kurniasih dan Siti Aminataz Alih Kode dan Campur Kode di Pondok Pesantren Mahasiswa Darussalam [Jurnal]. surakarta: journal Indonesian Language education and literature, 2017. - Vol. 3. 